\title{
Miranda
}

Revue pluridisciplinaire du monde anglophone /

Multidisciplinary peer-reviewed journal on the English-

speaking world

$20 \mid 2020$

Staging American Nights

\section{Oliver Tearle, The Great War. The Waste Land and the Modernist Long Poem}

\section{Xavier Kalck}

\section{OpenEdition}

\section{Journals}

\section{Electronic version}

URL: http://journals.openedition.org/miranda/22889

DOI: 10.4000/miranda.22889

ISSN: 2108-6559

Publisher

Université Toulouse - Jean Jaurès

\section{Electronic reference}

Xavier Kalck, "Oliver Tearle, The Great War. The Waste Land and the Modernist Long Poem", Miranda

[Online], 20 | 2020, Online since 19 March 2020, connection on 16 February 2021. URL: http:// journals.openedition.org/miranda/22889 ; DOI: https://doi.org/10.4000/miranda.22889

This text was automatically generated on 16 February 2021.

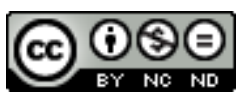

Miranda is licensed under a Creative Commons Attribution-NonCommercial-NoDerivatives 4.0 International License. 
Oliver Tearle, The Great War. The Waste Land and the Modernist Long

Poem

Xavier Kalck

\section{REFERENCES}

Oliver Tearle, The Great War. The Waste Land and the Modernist Long Poem. (London:

Bloomsbury, 2019), 208 p, ISBN: 9781350027015 


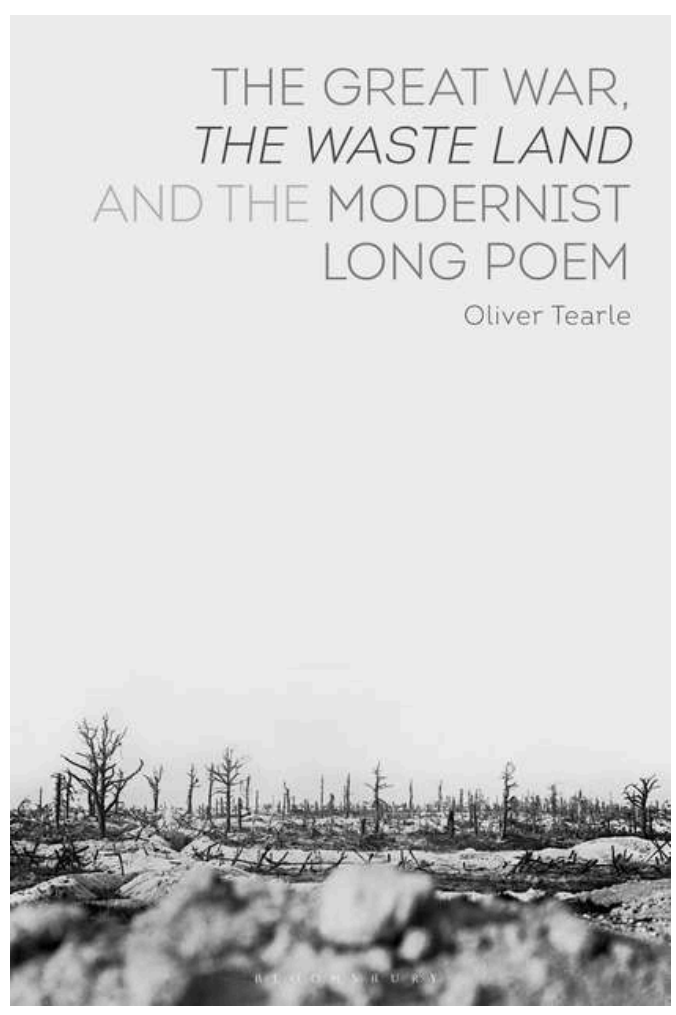

Oliver Tearle's study, The Great War, The Waste Land and the Modernist Long Poem, from Bloomsbury (2019), is a particularly welcome addition to the field of modernist studies in poetics inasmuch as it attempts to bring together competing lines of interpretation and often succeeds in finding a fruitful middle-ground. As the title clearly suggests, this book seeks to deal on an equal footing with a cultural, historical and material context (the Great War), with the specific text and as well as the general significance of Eliot's famous poem (The Waste Land), and with the genre that has come to be known as representative of high modernism in poetry (the Modernist Long Poem). Needless to say, this three-pronged approach might have proven unwieldy in other hands, and surely one feels tempted at times to request the book should delve more precisely into either of those three contiguous yet distinct levels of analysis. The difficult question of the very definition of the long poem might have been more thoroughly investigated, namely because Eliot's poem seems, in retrospect, not so very long indeed; but that is not Tearle's true focus here.

2 More importantly, Tearle beautifully manages to make the waste land of the early 1920s his and our own, well beyond the long shadow cast by Eliot's landmark publication-notably by turning to other, lesser-known and much less elegy-obsessed contemporaries. In other words, Tearle acknowledges the role of Eliot's poem within the canon and places it within its own milieu at the same time as he sets out on two different and equally important tasks. He initially seeks to replace Eliot's poem with other, sometimes competing, often parallel creations by some of Eliot's contemporaries. In doing so, Tearle also expands Eliot's work to the point that it might be decapitalized and conflated with the times-an instance of the times as much as the definition of an epoch. This results in an interesting and rich paradox, whereby Eliot's canonical piece is both minimized and maximized: its unique genius is called into question even as it becomes a commonplace, worthy of representing the entire period. 
3 After an introductory overview of the history and main characteristics of the modernist long poem, Tearle composes his exploration along six chapters, only one of which is actually devoted to Eliot's Waste Land (1922). Instead, Tearle is interested in Hope Mirrlees's Paris: A Poem (1920)-which until the early 2010s had been completely out of print; Ezra Pound's Hugh Selwyn Mauberley (1920); Eliot's “The Hollow Men” (1925); Richard Aldington's A Fool i' the Forest (1925) and Nancy Cunard's Parallax (1925). As these dates clearly indicate, Tearle's trajectory begins with forgotten precursors whose work undeniably allowed for Eliot's own to flourish and continues with the writings of poets who themselves answered, discussed, recused or picked up after Eliot, including Eliot himself with the transitional pre-conversion poem "The Hollow Men." Here lies the great quality of Tearle's endeavor, in that he does not desire to address the narrative of Anglo-American modernist poetry directly as a narrative, fraught with theory, potential generalities and sweeping statements, but from a carefully researched textual and contextual perspective. Eliot's centrality may be inescapable in these pages, yet this study uses The Waste Land rather as a starting point to paint the picture of a decade far richer and varied than this single "locus classicus of this literary form" might otherwise suggest.

4 In "Writing the Mother-City: Hope Mirrlees, Paris: A Poem," Tearle cannot demonstrate direct influence but asks: "If we did not know better, we would place Mirrlees's poem later than Eliot's." Deconstructing such illusions and expectations is at the heart of Tearle's project, which reveals a network of common concerns underneath individual efforts, while paying close attention to the way similar technical innovations lead to vastly different realizations. A case in point, Mirrlees's Paris, unlike Eliot's London, bears the marks of a much more buoyant avant-garde which distances it greatly from Eliot's particular sense of despair. With the next chapter, "Battered Books: Ezra Pound, Hugh Selwyn Mauberley," Tearle delves into Pound's initial effort to "self-modernize" and explains what paths Pound had taken that prepared him to edit Eliot's Waste Land in light of his own earlier post-war long poem. Tearle's analysis of Pound's quatrains proves particularly relevant in showing how and why Pound advised Eliot in a way that would prolong the destabilizing of the poetic voice with which he had himself already experimented. As he approaches Eliot in his fourth chapter, "A Poem without a Hero: T.S. Eliot, The Waste Land," Tearle evokes the fine balance between "the timeless and temporal existing together" in the poem, in which one recognizes the critic's own difficult balance between the canonical timelessness of Eliot's poem and its reconstructed coming into being, its contextualized temporal existence. This quite beautiful mirroring of the critic's task comes across most simply and convincingly, in a manner which proves very rewarding for the reader.

5 After having pointed to some of the shortcomings of Eliot's text compared with Mirlees's, Tearle turns to Eliot's own “The Hollow Men" to remind one that Eliot's Waste Land should be considered not as an individual piece, but within Eliot's overall trajectory toward conversion, which significantly alters how one might read both texts -not so much through the prism of an imagery of stunted growth, but as steps on the way of a growth which was once very nearly stunted, yet led to a rebirth. In the sixth chapter, "Arden to Ardennes: Richard Aldington, A Fool i' the Forest," Tearle moves away from Eliot more decisively as he presents ample evidence of the kind of rejection that Eliot's poetry elicited among his peers, while engaging with Eliot's poetic technique. Particularly fascinating are Aldington's efforts to rejuvenate the sterile landscape in 
Eliot and loosen the poet's use of free verse in a way that very interestingly connects the long poem to comparable experiments in narrative technique.

In "Nancy Cunard's Parallax and the 'Emotions of Aftermath'," Tearle's last chapter, he advocates against reading Cunard's poem mainly for her supposed indebtedness to Eliot and instead underlines the precise kind of parallax readers must be careful to detect, by saying that: "Cunard's poem is as much a response to Eliot's response to the war as it is a response to the war itself." Tearle's whole approach finds itself embodied in this fine example, in the sense that Eliot's success has come to overshadow the decade itself, to which his poem belongs, but not vice versa. The continuity of the use of Odysseus, from Mauberley to A Fool i' the Forest to Parallax, stands out as one among many examples of the very interconnected nature of Eliot's Joycean methodology. All these poets seem, in the end, like so many personae in a collective long poem of the aftermath of the Great War, each a separate and necessary part of the invention of modernism.

Although it is a pity that the William Carlos Williams and Louis Zukofsky American tradition of the long poem is only very briefly mentioned, when they constitute strong opponents to Eliot's new-founded tradition (written in 1926, Zukofsky's Poem Beginning "The" is a wonderful pastiche of Eliot's poem)-this reviewer only really finds fault here in the impression conveyed by the picture on the cover, a view of no man's land in the Marne in 1915. Contrary to what this picture might suggest, what Tearle succeeds to do in his book is to reveal how vibrant and plural these post-war years actually were. Perhaps the large white sky above the battlefield was meant to symbolize this: the blank page rising from dead trees, as a sign of reinvention, hovering above the ruins.

\section{INDEX}

Keywords: World War I, T.S. Eliot, The Waste Land, Modernism, long poem, modernist poetics Mots-clés: Première guerre mondiale, T.S. Eliot, The Waste Land, modernisme, poème long, poétique moderniste

\section{AUTHORS}

\section{XAVIER KALCK}

Maître de conférences

Sorbonne Université

xavier.kalck@sorbonne-universite.fr 